\title{
Teachers' Perceptions towards Pedagogical Implications of Code Switching: Saudi EFL Classroom Context in Focus
}

\author{
Abdulghani Mahdi ${ }^{1}$, Mansoor S. Almalki ${ }^{2 *}$ \\ English Language Centre, Deanship of Supportive Studies, Taif University, Saudi Arabia
}

*Corresponding Author: Mansoor S. Almalki, English Language Centre, Deanship of Supportive Studies, Taif University, Saudi Arabia

\begin{abstract}
This study investigates the perceptions of Saudi EFL learners towards the use of code switching inside the classroom. Using Sert's (2005) classification of code switching as the theoretical underpinning for the study, the research aims of analyze the related functions used by the teachers. Keeping in view the fact that the use of first language during the teaching of English inside the classroom is a pertinent as well as quite a widespread phenomenon, the study uses a detailed questionnaire to collect the data. This questionnaire contains both open and close-ended questions that are mainly based on the two research questions of the study. Although the prevailing perception towards code switching was negative, the results demonstrate that EFL teachers use code switching for various functions. The findings of the study indicate that the majority of the participants use code switching to assist low-level learners and to facilitate different language tasks. Most of the oft-used functions are noticed to be for the students' needs.
\end{abstract}

Keywords: Code Switching, Functions, EFL Teachers, L1 use in EFL Classrooms

\section{INTRODUCTION}

Researching issues pertaining to English language teaching and learning has become an important field in the academia. The main reason for this influx is the worldwide spread of the lingua franca itself. Consequently, academicians and researchers are faced with issues in both ESL and EFL contexts. The advent of globalizations as well as the technological advancement by the Global North have further strengthened the status of English language all over the world.

As an acknowledgment of this fact, English language teaching and learning were officially introduced in school curriculum by the Ministry of Education in the Kingdom of Saudi Arabia in 1925 (AlAhaydib, 1986). Moreover, many citizens of Saudi Arabia also consider English as a prestigious language, to be used to communicate effectively with people around the globe. Since 1925 onwards, English has become an essential part of curriculum in the Saudi Arabian education system.

The increasing demand for English language has led to many researches which cater for various issues related to its teaching and learning (Dawaele, 2019; Fuster\&Neuser, 2019; Pastor \&Barrera, 2019). One of these issues is code switching (Liu, 2018; Dlamini \&Kamwendo, 2018). Therehas been an increasing demand for, and a growing interest in, conducting researches that tackle the Saudi context regarding code switching. This study investigates the functions that EFL Saudi teachers utilize while code switching at EFL classrooms in the city of Jeddah. The study endeavors to figure out the main causes for code switching and its types.

\subsection{Research Questions}

- What are EFL teachers' perceptions regarding CS?

- What are the functions used by Saudi EFL teachers regarding code switching?

\subsection{Objectives of the Study}

The study aims to achieve the following objectives:

- To explore EFL teachers perceptions towards the use of CS in the EFL classroom

- To identify the functions of code switching among Saudi teachers 


\section{LITERATURE REVIEW}

Research on code switching has been on the increase since 1950s (Almulhim, 2014). In order to have a full understanding of code switching, definitions of the term must be reviewed first. Researchers have offered different definitions of code switching due to their varying perspectives of research, and to the context where it has been examined. Many definitions of the related terms overlap due to the similarities between these terminologies, such as borrowing and code mixing.

Gumperz (1982), one of the prominent pioneers in the field, defines code switching as "the juxtaposition within the same speech exchange of passages of speech belonging to two different grammatical systems or subsystems" (p.59). This definition refers to the alternation of two languages. From a grammatical point of view, Poplack (1980) defines the term of code switching as "The alternation of two languages within a single discourse, sentence or constituent" (p. 83). Similarly, Milroy and Muysken (1995) say that it is the alternative use by bilinguals of two or more languages in the same conversation.

Functions appeared to be classified in different forms. One of the most common classifications was done by Ferguson (2003), who outlined functions of code switching as follows: for curriculum, classroom management and interpersonal relationships. The first one, which is attached to curriculum and knowledge, offered in the classroom. The second is about controlling the classroom and monitoring learners' behavior. The third category is to improve the general atmosphere of the classroom to maintain interaction between learners and teachers.

Masrahi (2016) introduced another classification of code switching functions. He divided them into learning reasons and social reasons. His study was conducted to investigate the causes of code switching by low-level EFL learners at Jazan University, KSA.

Code switching was also used for the purpose of exploring the identity of two individuals in their first meeting (Al-rowais, 2012). It might be used to build linguistic solidarity between speakers who share ethno-cultural identity, and to improve interpersonal relationship between people who have the same code (Modupeola, 2013).

There were many studies conducted in the Arab region in general, but few investigations involved the Saudi Arabian context, despite the fact that it is an EFL country, where English is considered as a foreign language. In addition to that, the need for studies that investigate the use of code switching increases when we realize that the kingdom has a huge number of foreigners who have no communication means other than using English (Sipra, 2007). The matter of investigating code switching in Saudi Arabia is worth a broad and extended research in order to investigate its different dimensions. It is a widespread phenomenon in EFL classes as indicated by Al Balawi (2016), saying that up to $80 \%$ of the EFL teachers in the Kingdom use L1 (Arabic). In her study, teachers showed positive attitude towards the use of mother tongue in some cases such as explaining new concepts and vocabulary, introducing grammar and checking comprehension.

A study conducted by AbdelMagid and Mugaddam (2013) in the context of two Arabic speaking countries (Saudi Arabia and Sudan) claimed that code switching is unavoidable behavior by EFL teachers, and it is easier and natural to communicate with others who share the same L1. Moreover, the study suggested that L1 is crucial as an essential part of language teaching and learning. This is not in line with the study conducted by Al Adnani and Elyas (2016), which stated that code switching should not be recommended in the language classroom. The findings of the research indicated that there was a clear difference between the grades of the learners whose teachers used code switching, compared to those who did not.

Al Nofaie (2010) reported in her study that the majority of teachers who participated in her study showed a positive attitude towards code switching, and they revealed that they use it for different purposes. However low-level students were a strong stimulus for the teachers to code switch. The needs of weak students to clarify difficult tasks compelled teachers to use their L1. Al Nofaie argued that this was an unavoidable phenomenon. Khresheh (2012) added a significant function of teachers' code switching that is the cultural differences between the two languages involved in the process of code switching. These differences force teachers to illustrate the cultural concept of the target language, using the mother tongue of their students. 
Al Asmari's (2014) study revealed a vital finding that the teachers who participated in his investigation prefer that EFL teachers should be bilinguals to achieve high levels in their students' proficiency. It is also recommended in the study that more professional use of the mother tongue should be ensured, and extra measures should be carried out to achieve the maximum pedagogical benefits.

\section{THEORETICAL FRAMEWORK}

The focus of this study is to investigate and identify EFL teachers' usage of code switching. There are various theories that offer the framework of code switching analysis. This research has adopted the framework from Sert's (2005) study that has also been listed by Mattson and Burenhult (1999). It will be employed in data analysis. These functions as mentioned in the study are as follows: topic switch, repetitive functions and affective functions.

\subsection{Topic Switch}

Sert (2005) identifies that when teachers code switch to the mother tongue of the learners, they draw learners' attention to the new knowledge taught, such as grammar instruction. In this case, Sert believes that teachers will create links between the known mother language (native language) and the unknown target language (new foreign language).

\subsection{Affective Functions}

Sert (2005) argues that code switching has also affective functions that might bring solidarity and develop strong rapport as well as intimate relations between teachers and learners. He emphasizes on the supportive language environment that such functions of code switching might create.

\subsection{Repetitive Functions}

The third function of teachers' code switching in Sert's study is repetitive functions. In these functions, the teacher transfers the most important instruction in the classroom in the learners' mother tongue to ensure clarity. Teachers repeat some utterances in both L1 and L2 to ensure that learners understand the target language. On the other hand, he alerted teachers of the negative consequences of the excessive use of the mother tongue in their academic processing and their interest in the target language.

\section{Methodology}

The study employs a mixed approach of research that combines qualitative and quantitative methods. Data collection process was only limited to a detailed questionnaire. The study is conducted in the schools of the city of Jeddah, it is known for its largeness, and this could be beneficial to apply the results of this study to other cities that have the same nature. The participants of the study are English teachers in both public and private schools. The participants of the study were selected randomly from both intermediate and secondary schools, public and private, and both males and females to ensure that they represent the whole cohort of EFL teachers in the city of Jeddah. The reason behind not to include primary school teachers is that English is not fully established in primary schools.

Regarding the data collection process, a detailed questionnaire that combines both close-ended and open-ended questions was circulated among the participants. The questionnaire is developed in the light of the study questions and employed the classifications of code switching functions listed by Sert (2005). These functions are topic switch, affective functions and repetitive functions. The questionnaire has one open-ended question that has been analyzed qualitatively; this question is matching the first question of this study and paving the way to its analysis. The question consists of two parts, as follows:

Will using the mother language in the EFL classroom affect the learner positively or negatively? How?

The close-ended section comprises of nine statements that are related to the functions of code switching by teachers; they were divided to cover the three main items of the classification by Sert (2005).

\subsection{Data Analysis}

The research employed qualitative and quantitative methods (mixed approach) to analyze the data obtained from the questionnaire. As mentioned previously, the actual questionnaire consisted of two sections: close-ended and open-ended questions. The collected data for close-ended questions were analyzed quantitatively and data collected for open-ended questions were analyzed qualitatively. 
Analyzing the data that are provided by the questionnaire, went through descriptive statistics using (SPSS), the statistical package for the social sciences. Functions of code switching and their findings were transferred into codes to be operated by the program, using Microsoft Excel and then piped to SPSS.

\section{ReSUlts}

\subsection{Results of Question 1}

In order to elicit participants' responses for this question and analyze them quantitatively and qualitatively, this question had two segments of close and open questions. The question was (Would using the mother language in EFL classroom affect the learner positively or negatively? How?). Responses to this question showed the prevailing perception towards code switching as teachers seemed to be strict about the use of the mother language in an EFL classroom.

Table1. Participants' perceptions of CS

\begin{tabular}{|l|l|l|l|l|}
\hline \multicolumn{2}{|c|}{ Frequency } & \multicolumn{1}{c|}{ Valid Percent } & \multicolumn{1}{c|}{ Cumulative Percent } \\
\hline \multirow{5}{*}{ Valid } & Positively & 28 & 41.8 & 41.8 \\
\cline { 2 - 5 } & Negatively & 39 & 58.2 & 85.2 \\
\cline { 2 - 5 } & Total & 67 & 100.0 & 100.0 \\
\hline Missing & System & 1 & & \\
\hline Total & 68 & & \\
\hline
\end{tabular}

Results of this question as shown in table (1) indicate that the overwhelming majority with a percentage of $58.2 \%$ consider code switching as a negative strategy in EFL classrooms, while $41.8 \%$ of the participants believe that it is positive and useful. The cohort of the opponents provided their supporting arguments as well as the supporters. In the following section, these responses are discussed.

Responses that were provided by teachers who are opponents of the use of code switching revolved around the negativity of the use of L1 in EFL classrooms. They argued that students might pay less attention and interest to the target language. They also highlighted the point that learners may heavily depend on the teacher assistance in each activity and wait for translation. Teachers explained their reason to support the ban of L1 in EFL classrooms in order to enable learners to use and practice the language since it is difficult for them to use it outside the classroom. This is in accordance with the findings of Al Nofaie's (2010) study, that teachers tried to avoid Arabic for the same reason in all activities such as explaining a new grammar rule, expressing opinion and even checking learners' understanding.

On the other hand, participants who are in favor of the use of L1 in EFL classrooms argued that code switching is a helpful tool to teach low-level learners and check their understanding. They emphasized that this can build their confidence and increase their motivation to learn more. The main reason for teachers to code switch is to enable them to understand their speech (Flyman-Mattson and Burenhult, 1999).

There are various functions that teachers often utilize which are worthy of discussion and deep analysis. The following section answers the second question of the research and analyzes the functions that EFL teachers use in EFL classrooms in Saudi Arabia.

\subsection{Results of Question 2}

Functions of code switching introduced in the questionnaire of the current study were divided under three categories according to the theoretical framework developed by Sert (2005). For topic switch, ten items are discussed.

\subsubsection{Topic Switch}

Items that are analyzed under this classification are functions, which teachers utilize when they want to draw learners' attention to the topic, discussed in the classroom, particularly grammar explanation and so forth.

a) To Explain Grammar Rules

Table2. To explain Grammar rules

\begin{tabular}{|l|l|l|l|l|l|}
\hline \multicolumn{2}{|c|}{} & Frequency & \multicolumn{1}{|c|}{ Valid Percent } & \multicolumn{1}{c|}{ Mean } & \multicolumn{1}{c|}{$\mathbf{2 . 4 0}$} \\
\hline Valid & Always & 18 & 26.9 & Median & 2.00 \\
\cline { 2 - 6 } & Often & 19 & 28.4 & Mode & 2 \\
\cline { 2 - 6 } & Sometimes & 18 & 26.9 & Std. Deviation & 1.155 \\
\cline { 2 - 6 } & Rarely & 9 & 13.4 & Sum & 161 \\
\cline { 2 - 6 } & Never & 3 & 4.5 & & \\
\hline
\end{tabular}


Teachers' Perceptions towards Pedagogical Implications of Code Switching: Saudi EFL Classroom Context in Focus

\begin{tabular}{|l|l|l|l|}
\hline & Total & 67 & 100.0 \\
\cline { 1 - 3 } Missing & System & 1 & \\
\cline { 1 - 4 } Total & 68 & \\
\cline { 1 - 3 }
\end{tabular}

The above mentioned table illustrates that 18 respondents referred to this function (26.9\%) of code switching as they always use it in the classroom. Similarly, 19 subjects $(28.4 \%)$ responded that they often use it. Moreover, 18 participants (26.9\%) use CS sometimes in the classroom for this function. All in all, 9 respondents $(13.4 \%)$ chose it rarely and 3 participants $(4.5 \%)$ never used L1 for explaining grammar. The sample mean was 2.40 and standard deviation was 1.155 .

As it can be obviously seen that the majority of participants were in favor of using L1 to explain grammar rules, this is in accordance with the finding of Al-Abdan's (1993) study that $(54.5 \%)$ of Saudi English teachers prefer to use Arabic while explaining grammar. Cook (2001) also supported this opinion in her article that code switching can assist learners to understand grammar better.

\section{b) To Explain Difficult Concepts}

Teachers who participated in the study used code switching for the function of explaining difficult concepts to a great extent. Table 3 demonstrates that the majority of the participants $(35.8 \%)$ were using it sometimes. However, $32.8 \%$ of the participants used it often and $22.4 \%$ use code switching always in the classroom. Only 5 participants, representing $7.5 \%$ of the total, used it rarely while 1 (1.5\%) participant never used it for this function. The mean was 2.33 and the standard deviation sample was .960 .

Table3. To explain difficult concepts

\begin{tabular}{|l|l|l|l|l|l|}
\hline \multicolumn{2}{|c|}{} & Frequency & Valid Percent & Mean & $\mathbf{2 . 3 3}$ \\
\hline Valid & Always & 15 & 22.4 & Median & 2.00 \\
\cline { 2 - 5 } & Often & 22 & 32.8 & Mode & 3 \\
\cline { 2 - 4 } & Sometimes & 24 & 35.8 & Std. Deviation & .960 \\
\cline { 2 - 4 } & Rarely & 5 & 7.5 & Sum & 156 \\
\cline { 2 - 4 } & Never & 1 & 1.5 & \\
\cline { 2 - 4 } & Total & 67 & 100.0 & \\
\hline Missing & System & 1 & & \\
\cline { 1 - 3 } Total & 68 & & \\
\end{tabular}

\section{c) To Translate the Meaning of New Vocabulary}

Translation to the target language is one of the popular ways that teachers employ during EFL classrooms. Instead of continuing explaining in the foreign language, teachers tend to translate new vocabulary items for students to keep their interest. It is a shortcut to decrease the comprehension burden for learners instead of spending much time in explaining vocabulary and concentrating on the main point of the lesson. In fact, it is considered as one of the best teaching devices. This goes in line with the study of Franklin (1990) that translating vocabulary to the mother tongue of the learner is a common behavior of language teachers. In beginner levels, Nation (2003) suggests that vocabulary of the target language should be translated to the mother language.

The results regarding this function in table (4) show that $28.4 \%$ of the respondents always use translation while $13.4 \%$ often use it in the classroom. Similarly, $26.9 \%$ of the participants prefer to use it sometimes and $22.4 \%$ rarely use it. Only $9.0 \%$ never use translation. The sample mean was 2.70 and the standard deviation was 1.337 .

Table4. To translate the meaning of new vocabulary

\begin{tabular}{|c|c|c|c|c|c|}
\hline & & Frequency & Valid Percent & Mean & 2.70 \\
\hline \multirow[t]{6}{*}{ Valid } & Always & 19 & 28.4 & Median & 3.00 \\
\hline & Often & 9 & 13.4 & Mode & 1 \\
\hline & Sometimes & 18 & 26.9 & Std. Deviation & 1.337 \\
\hline & Rarely & 15 & 22.4 & Sum & 181 \\
\hline & Never & 6 & 9.0 & & \\
\hline & Total & 67 & 100.0 & & \\
\hline Missing & System & 1 & & & \\
\hline \multicolumn{2}{|l|}{ Total } & 68 & & & \\
\hline
\end{tabular}




\section{AfFECTIVE FunCTIONS}

Items that are analyzed under this classification are functions, which teachers utilize when they want to express emotions and build a close relationship with learners. They usually use L1 while employing these functions to develop rapport with students to create a comfortable learning environment.

\subsection{For Humor/ Telling Jokes}

Teachers sometimes tend to change the general atmosphere of the classroom to avoid monotony and to create effective environment. Teachers prefer to bring sense of humor to the classroom by telling some jokes. Humor is a good way to relieve stress among learners and develop rapport with them, this kind of relationship between teachers and learners is vital to enhance the learning pace of the students.

Nevertheless, teachers must pay attention to the negative effects of humor; they should be moderate while using it. Teachers should be intelligent and guess the reaction of the classroom before using humor (Spare, 2008).

To do so, most of the learners are likely not to understand different kinds of humor in English; therefore, teachers switch to tell jokes in L1. Despite the significance of humor in the EFL classroom, the results of this function in table 5 showed different views. A major $53.7 \%$ of the participants sometimes use it, and $14.9 \%$ always use it. While $7.5 \%$ of the respondents often use it. Those who rarely use this function were $16.4 \%$ while those who never use it were $7.5 \%$. The mean was 2.94 and the standard deviation was 1.071 .

Table5. For humor/ telling jokes

\begin{tabular}{|l|l|l|l|l|l|}
\hline \multirow{4}{*}{ Valid } & Frequency & Valid Percent & Mean & 2.94 \\
\cline { 2 - 5 } & Always & 10 & 14.9 & Median & 3.00 \\
\cline { 2 - 5 } & Often & 5 & 7.5 & Mode & 3 \\
\cline { 2 - 5 } & Sometimes & 36 & 53.7 & Std. Deviation & 1.071 \\
\cline { 2 - 4 } & Rarely & 11 & 16.4 & Sum & 197 \\
\cline { 2 - 4 } & Never & 5 & 7.5 & \\
\cline { 2 - 4 } & Total & 67 & 100.0 & \\
\hline Missing & System & 1 & & & \\
\hline Total & 68 & & & \\
\hline
\end{tabular}

\subsection{To Find Out Students' Reaction to the Teaching}

Teachers differ in their ways of teaching; they follow various styles and methods. Regarding this fact, some teachers prefer to check their students' reaction to their teaching style; this could help teachers to implement methods that are more effective.

Table6. To find out students' reaction of to the teaching

\begin{tabular}{|l|l|l|l|l|l|}
\hline \multirow{4}{*}{ Valid } & Always & 13 & Valid Percent & Mean & 2.63 \\
\cline { 2 - 6 } & Often & 14 & 19.4 & Median & 3.00 \\
\cline { 2 - 4 } & Sometimes & 29 & 20.9 & Mode & 3 \\
\cline { 2 - 4 } & Rarely & 7 & 43.3 & Std. Deviation & 1.099 \\
\cline { 2 - 4 } & Never & 4 & 10.4 & & 176 \\
\cline { 2 - 4 } & Total & 67 & 6.0 & & \\
\hline Missing & System & 1 & 100.0 & \\
\hline \multicolumn{1}{|l|}{ Total } & 68 & & & \\
\hline
\end{tabular}

Results in table 6 indicate that $19.4 \%$ of the participants always utilize this function and $20.9 \%$ often use it, while $43.6 \%$ use it sometimes. Only $10.4 \%$ of the respondents rarely use it and the lowest ratio $6.0 \%$ goes to those who never code switch to find out their students' reaction.

\subsection{Use Code Switching for Praising}

Praising learners for their achievements is a recommended strategy to increase their motivation. Teachers praise learners for various reasons, such as when they answer a question or participate in an activity. It can have a positive effect on students' learning and increase their pace of processing. The results in table 7 show that the majority $(28.4 \%)$ rarely code switch for this function, while $23.9 \%$ used it sometimes. However, $19.4 \%$ use it often, and $16.4 \%$ use it always. Only $11.9 \%$ of the participants never use it. The sample mean was 3.00 and the sample standard deviation was 1.279. 
Teachers' Perceptions towards Pedagogical Implications of Code Switching: Saudi EFL Classroom Context in Focus

Table7. Use code switching for praising

\begin{tabular}{|c|c|c|c|c|c|}
\hline & & Frequency & Valid Percent & Mean & 3.00 \\
\hline \multirow{6}{*}{ Valid } & Always & 11 & 16.4 & Median & 3.00 \\
\hline & Often & 13 & 19.4 & Mode & 4 \\
\hline & Sometimes & 16 & 23.9 & Std. Deviation & 1.279 \\
\hline & Rarely & 19 & 28.4 & Sum & 201 \\
\hline & Never & 8 & 11.9 & & \\
\hline & Total & 67 & 100.0 & & \\
\hline Missing & System & 1 & & & \\
\hline \multicolumn{2}{|l|}{ Total } & 68 & & & \\
\hline
\end{tabular}

\section{REPETITIVE FUNCTIONS}

This is the third category of Sert' classifications of code switching's functions. Items that are discussed under this classification are functions, which teachers utilize when they want to transfer important points to students for clarity; they repeat some utterances in L1 after their synonyms in L2 to confirm understanding of the learners. Flyman-Mattson and Burenhult (1999) clearly define this function: "the repetition in the first language can be either partial or full, and is often expanded with further information, but more frequently code switching is used as a repetition of the previously uttered sentences" (p.11). The following four functions are analyzed in this category.

\subsection{To Check Comprehension}

It is one of the teaching strategies to check learners' comprehension by several means; teachers often check comprehension by switching to the mother tongue of learners. They repeat important points to check whether they are comprehended.

Table8. To check comprehension

\begin{tabular}{|c|c|c|c|c|c|}
\hline & & Frequency & Valid Percent & Mean & 2.67 \\
\hline \multirow{6}{*}{ Valid } & Always & 18 & 26.9 & Median & 3.00 \\
\hline & Often & 12 & 17.9 & Mode & 1 \\
\hline & Sometimes & 16 & 23.9 & Std. Deviation & 1.307 \\
\hline & Rarely & 16 & 23.9 & Sum & 179 \\
\hline & Never & 5 & 7.5 & & \\
\hline & Total & 67 & 100.0 & & \\
\hline Missing & System & 1 & & & \\
\hline \multicolumn{2}{|l|}{ Total } & 68 & & & \\
\hline
\end{tabular}

As the results in table (8) indicates, $26.9 \%$ of the participants always use this function and $17.9 \%$ often use it, while $23.9 \%$ sometimes use it. The same percentage goes to those who rarely use it and only $7.5 \%$ for those who never code switched to check learners' comprehension. The mean was 2.67 and the standard deviation was 1.307.

\subsection{Code Switching for Discipline Purposes}

Some students need to be disciplined by the teacher inside the classroom, when the teacher deals with them; he/she often switches to L1 and repeats disciplining words, if necessary. Results of this function in table (9) show that $13.4 \%$ of the respondents always use code switching for disciplining purposes, and $23.9 \%$ of participants often use it.

Those who sometimes use this function were $34.3 \%$ of the respondents while $25.4 \%$ use it rarely, and only $3.0 \%$ never use it. The sample mean was 2.81 and the standard deviation was 1.062 .

Table9. Code switching for discipline purposes

\begin{tabular}{|l|l|l|l|l|l|}
\hline \multirow{5}{*}{ Valid } & Frequency & Valid Percent & Mean & 2.81 \\
\cline { 2 - 5 } & Always & 9 & 13.4 & Median & 3.00 \\
\cline { 2 - 5 } & Often & 16 & 23.9 & Mode & 3 \\
\cline { 2 - 4 } & Sometimes & 23 & 34.3 & Std. Deviation & 1.062 \\
\cline { 2 - 4 } & Rarely & 17 & 25.4 & Sum & 188 \\
\cline { 2 - 4 } & Never & 2 & 3.0 & \\
\cline { 2 - 4 } & Total & 67 & 100.0 & \\
\hline Missing & System & 1 & & \\
\hline \multicolumn{1}{|l|}{ Total } & 68 & & \\
\hline
\end{tabular}


Teachers' Perceptions towards Pedagogical Implications of Code Switching: Saudi EFL Classroom Context in Focus

\subsection{To Get the Attention of the Students in the Class}

Table10. To get the attention of the students in the class

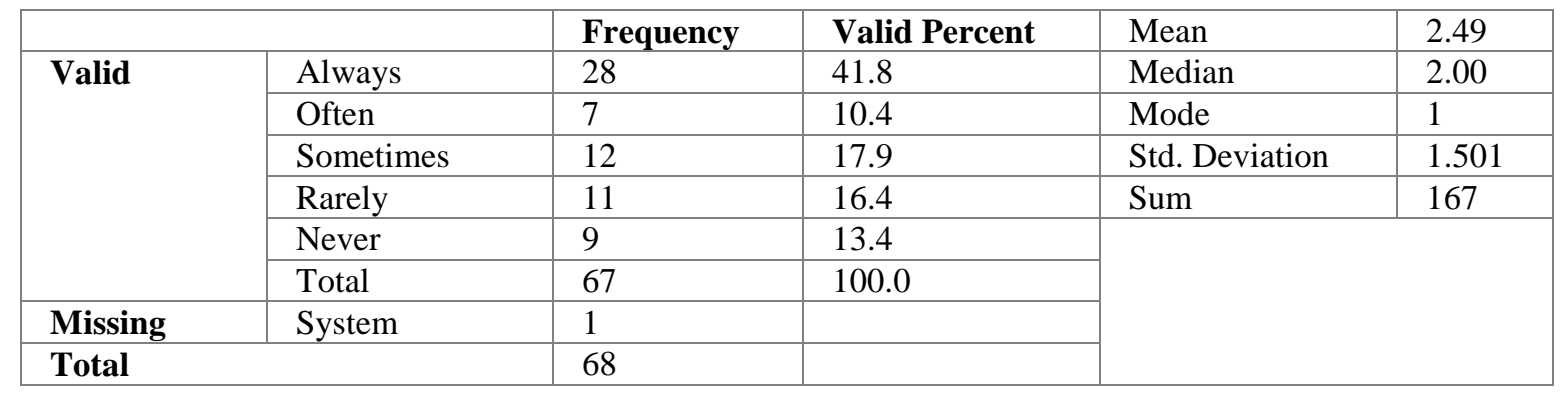

Code switching can serve as attention-getting device that teachers utilize when they want to attract the attention of the class. They switch and repeat some words from L1. This strategy could be useful while dealing with some absent-minded learners. The analysis of the presented results demonstrates that a considerable number of participants $(41.8 \%)$ always code switch for this reason while $10.3 \%$ of the participants often use it, and $17.9 \%$ sometimes utilize it in the classroom. However, $16.4 \%$ of the respondents rarely use it, whereas $13.4 \%$ of them never used it. The mean was 2.49 and the standard deviation was 1.501 .

\section{CONCLuSion}

Based on the findings of this research, there was a negative perception amongst participants towards code switching. This was in accordance with the prevailing perception of code switching. The overwhelming majority of the respondents have not supported using L1 in the EFL classroom. Moreover, the study revealed that the main reason for teachers to avoid code switching is that learners' opportunities to practice the target language was very little. The functions that are presented in this study are discussed in terms of the classification of code switching proposed by Mattson and Burenhult (2001), and later developed by Sert (2005). The study revealed that code switching in Saudi EFL classrooms is a prevalent phenomenon. It provides an overview of the general situation and the positive use of code switching in teaching the foreign language. The findings of this study demonstrated that participants' use of code switching was for the benefit of the students, and they have shown that using the first language of the learners can play a significant role in their overall comprehension. Although the prevailing perception and the literature of using L1 has received negative background in many researches as bilingual teachers may support and facilitate the learning process of their students by using L1 in a moderate methodology.

\section{REFERENCES}

[1] Abdel Magid, M. E., \&Mugaddam , A. H. (2013). Code switching as an interactive tool in ESL classrooms. Vol. 2, No, 2, 2013, English Linguistics Research.

[2] Al-Abdan, A. A. (1993). 'A study on using Arabic in teaching English in Saudi intermediate schools', King Saud University Magazine, 50(2), pp. 396-426.

[3] Al-Adnani, A., \&Elyas, T. (2016). The Effect of teacher's code-Switching on students' Achievement in Speaking in the EFL Context, The European Conference on Language Learning 2016. The International Academic Forum.

[4] Al-Ahaydib, M. E. (1986). Teaching EFL in the intermediate and secondary schools of Saudi Arabia: diagnostic study. Unpublished PhD thesis. University of Kansas.

[5] Al-Asmari, A. (2014). Teachers" Perceptions about the Use of Mother Tongue in Saudi EFL University Classrooms: A Gender-line Investigation. Vol. 4, No. 10, pp. 2066-2075, October 2014, Theory and Practice in Language Studies.

[6] Al-Balawi, F. S. (2016). The Attitudes of Saudi EFL Teachers about Using Their Mother Tongue in EFL Classrooms. Vol. 3 No.7, 2016, International Journal of Education and Social Science.

[7] Almulhim, F. K. (2014). Am I allowed to use Arabic? A case study of the functions of, and attitudes towards codeswitching in a Saudi Arabian EFL classroom. PhD thesis. Newcastle University.

[8] AlNofaie, H. (2010). The Attitudes of Teachers and Students Towards Using Arabic in EFL Classrooms in Saudi Public Schools- A case study, Novitas-ROYAL (Research on Youth and Language), 2010, 4 (1), 64 95. 
[9] Al-rowais, H. (2012). Code Switching between Arabic and English, social motivations and structural constraints. MA thesis. Ball State University.

[10] Ana Maria Relaño-Pastor \& Alicia Fernández-Barrera (2019) The 'native speaker effects' in the construction of elite bilingual education in Castilla-La Mancha: tensions and dilemmas, Journal of Multilingual and Multicultural Development, DOI: 10.1080/01434632.2018.1543696

[11] CarlesFuster\& Hannah Neuser (2019) Exploring intentionality in lexical transfer, International Journal of Multilingualism, DOI: 10.1080/14790718.2018.1559845

[12] Cook, V. (2001). 'Using the first language in the classroom', Canadian Modern Language Review/La Revue Canadienne des LanguesVivantes, 57(3), pp. 402-423.

[13] Ferguson, G. (2003). Classroom Code-Switching in Post-Colonial Contexts: Functions, Attitudes and Policies. AILA Review, 16, 38-51.

[14] Franklin, C. E. (1990). Teaching in the target language: problems and prospects. Language Learning Journal, 2, p. 20-24.

[15] Gumperz, J. J. (1982). Discourse strategies. Cambridge: Cambridge University Press.

[16] Hong Liu (2018) A socio-cognitive approach to code-switching: from the perspective of a dynamic usagebased account of language, International Journal of Bilingual Education and Bilingualism, DOI: $10.1080 / 13670050.2018 .1441260$

[17] Jean-Marc Dewaele (2019) Multilingualism and trait emotional intelligence: an exploratory investigation, International Journal of Multilingualism, DOI: 10.1080/14790718.2019.1571065

[18] Khresheh, A. (2012). Exploring When and Why to Use Arabic in the Saudi Arabian EFL Classroom: Viewing L1 Use as Eclectic Technique. Vol. 5, No. 6, 2012, English Language Teaching.

[19] Masrahi , N. (2016). Causes of Code Switching by Low Level EFL Learners at Jazan University, Saudi Arabia: A Teachers' Perspective. Vol. 2, No. 4, 2016, pp. 24-31, Journal of Language, Linguistics and Literature.

[20] Mattson, A., \&Burenhult-Mattson , N. (1999). Code-switching in second language teaching of French. Working Papers 47: 59-72.

[21] Milroy, L., \&Muysken, P. (eds). (1995). One Speaker, Two Languages: Cross-Disciplinary Perspectives on Codeswitching. New York, NY: Cambridge University Press.

[22] Modupeola, R. O. (2013). Code- Switching as a teaching strategy: Implication for English Language teaching and learning in a multilingual society. Vol. 14, Issue 3, 2013, pp 92-94, IOSR Journal Of Humanities And Social Science (IOSR-JHSS).

[23] Nosisi P. Dlamini \& Gregory H. Kamwendo (2018) Code-switching as a Strategy for the Decolonisation of Learning: A Case of One University in Swaziland, International Journal of African Renaissance Studies - Multi-, Inter- and Transdisciplinarity, 13:1, 39-55, DOI: 10.1080/18186874.2018.1479873

[24] Poplack, S. (1980). Sometimes I'll start a sentence in Spanish y terminoenespanol: toward a typology of code-switching. Linguistic 18, pp. 581-618.

[25] Sert, O. (2005). The Functions of Code Switching in ELT Classrooms. The Internet TESL Journal, XI(8). Retrieved from http://iteslj.org/Articles/Sert-CodeSwitching.html.

[26] Sipra, M. A. (2007). Bilingualism as teaching aid in a language class: L1 as a facilitator in teaching/ learning process of L2 at intermediate/certificate level. Unpublished Doctoral Dissertation, National University of Modern Languages, Islamabad.

Citation: Abdulghani Mahdi, Mansoor S. Almalki. "Teachers' Perceptions towards Pedagogical Implications of Code Switching: Saudi EFL Classroom Context in Focus" International Journal on Studies in English Language and Literature (IJSELL), vol 7, no. 3, 2019, pp. 1-9. doi: http://dx.doi.org/10.20431/2347 3134.0703001.

Copyright: () 2019 Authors. This is an open-access article distributed under the terms of the Creative Commons Attribution License, which permits unrestricted use, distribution, and reproduction in any medium, provided the original author and source are credited. 